Article

\title{
Long-Term Care and Gender Equality: Fuzzy-Set Ideal Types of Care Regimes in Europe
}

\author{
Attila Bartha ${ }^{1,2, *}$ and Violetta Zentai ${ }^{3}$ \\ ${ }^{1}$ Centre for Social Sciences, Hungarian Academy of Sciences Centre of Excellence, 1097 Budapest, Hungary; \\ E-Mail: bartha.attila@tk.mta.hu \\ 2 Department of Public Policy and Management, Corvinus University of Budapest, 1093 Budapest, Hungary \\ ${ }^{3}$ Center for Policy Studies, Central European University, 1051 Budapest, Hungary; E-Mail:zentaiv@ceu.edu \\ * Corresponding author
}

Submitted: 3 March 2020 | Accepted: 6 July 2020 | Published: 9 October 2020

\begin{abstract}
Recent changes in the organization of long-term care have had controversial effects on gender inequality in Europe. In response to the challenges of ageing populations, almost all countries have adopted reform measures to secure the increasing resource needs for care, to ensure care services by different providers, to regulate the quality of services, and overall to recalibrate the work-life balance for men and women. These reforms are embedded in different family ideals of intergenerational ties and dependencies, divisions of responsibilities between state, market, family, and community actors, and backed by wider societal support to families to care for their elderly and disabled members. This article disentangles the different components of the notion of '(de)familialization' which has become a crucial concept of care scholarship. We use a fuzzy-set ideal type analysis to investigate care policies and work-family reconciliation policies shaping long-term care regimes. We are making steps to reveal aggregate gender equality impacts of intermingling policy dynamics and also to relate the analysis to migrant care work effects. The results are explained in a four-pronged ideal type scheme to which European countries belong. While only Nordic and some West European continental countries are close to the double earner, supported carer ideal type, positive outliers prove that transformative gender relations in care can be construed not only in the richest and most generous welfare countries in Europe.
\end{abstract}

\section{Keywords}

care regimes; familialization; fuzzy set ideal type analysis; gender equality; long-term care; migrant care work

\section{Issue}

This article is part of the issue "Division of Labour within Families, Work-Life Conflict and Family Policy" edited by Michael Ochsner (FORS Lausanne, Switzerland), Ivett Szalma (Centre for Social Sciences, Hungarian Academy of Sciences Centre of Excellence, Hungary/Corvinus University of Budapest, Hungary) and Judit Takács (Centre for Social Sciences, Hungarian Academy of Sciences Centre of Excellence, Hungary/KWI Essen, Germany).

(C) 2020 by the authors; licensee Cogitatio (Lisbon, Portugal). This article is licensed under a Creative Commons Attribution 4.0 International License (CC BY).

\section{Introduction}

Care is a complex system at the intersections of several human relations, social practices, and public affairs that shape the demand, provision, and norms of managing physical and emotional assistance to people in need. Care relates to concerns with ageing of European populations, work-life family balance, structures of the labor market, and patterns of labor migration. Care can be a source of pride, dignity, and solidary bond for both the carer and the cared-and it can be a major burden on both parties. Care embodies and shapes various gender in/equality patterns, including the sharing of care responsibilities in family and societal settings, and the access to jobs of variegated social security and pension consequences. When migration becomes a major link between different components of care systems, gender equality considerations multiply. Macro-level inequali- 
ties related to the differences in wealth in societies of the Global South and the Global North, and most recently of the old and the new member states of the EU, are interlinked with micro-level inequalities within the family as well as between caregivers and care receivers (Lutz, 2018; van Hooren, Apitzsch, \& Ledoux, 2019). As a consequence, care work is embedded in complex hierarchies and power relations between the employer and the employee, the carer and the cared, and the citizens and the migrant workers of a country, and thus mirrors inequalities linked to gender and various other grounds, including ethnicity, nationality, race, and citizenship status. Care provision allows some (mostly men and some women) to engage in paid labour and spend less time in unpaid domestic work, providing support for children, elderly, and sick family members. At the same time, recognition of domestic care as paid work creates opportunities for others (mostly women) to pursue paid employment within the domestic sphere. All this has tangible, in many respects transformative, impacts on gender relations in society, but does unleash new forms of inequalities as well.

The welfare policy literature provides plenty of theoretical and empirical knowledge on the links between care regimes and the in/equality properties of gender relations. Gender studies and feminist scholars have contributed to refine welfare regime typologies, to conceptualize family policies (Daly, 2011), and by putting the problem of care to the front of welfare thinking, to link gender configurations to various other constitutive forces of welfare (Lewis, 2006). In the latter inquiry, scholarship has cast light on the relations and tensions between paid work and care. Nancy Fraser's (1994) work, most notably the universal caregiver ideal, has inspired generations of scholars in search of gender justice. In Fraser's model, a fair redistribution of care and paid work contributes to feminist theorizing on social citizenship which is anchored in production and reproduction in societal terms (Lewis \& Giullari, 2005; Lister, 1997). A gender division of labor in family and society fundamentally shapes the possibilities of men and women in participation in production. Conversely, women's independent income from paid work and social benefits enhances their bargaining power in making household decisions. At the macrolevel, public policies intervening in relations of production and reproduction can alter the historically constituted and legitimized unequal gender division of time, resources, and recognition (Ciccia \& Sainsbury, 2018).

In our earlier work (Bartha, Fedyuk, \& Zentai, 2015), we sought to explore the linkages of care regimes, gender equality policy regimes, and migration policy effects in European polities by addressing childcare and elderly (as well as disabled and sick) care together. Despite the obvious overlaps between care work for children and elderly in both micro and macro settings, scholarly investigations also dwell on these domains of care independently. Research is more robust and well documented on the former, whereas it has taken off in the latter field in the last couple of years. Therefore, in this article we present the first results of research which uncovers longterm care (LTC) patterns in Europe through sharpening our enduring interest on the care, gender equality, and migration policy triangle (Williams, 2012). The inquiry intends to capture some trends that partly started before the emergence of the 2008 crisis but unfolded in the 2010s. It also attempts to link LTC models and workfamily reconciliation policies. We are making the first steps to reveal aggregate gender equality impacts of intermingling policy dynamics and also to link in the analysis of care chain effects that connect as well as separate the old and the new member states in the EU.

\section{Theoretical Framework: Long-Term Care and Gender In/Equality in Europe}

The European Pillar of Social Rights includes access to affordable and good quality LTC services as one of its core principles. Most European states face population ageing in the medium- to longer-term due to longer life expectancies in societies of decreasing birth rates. It is expected that the ratio of Europeans aged $80+$ will rise from the present $5 \%$ to $13 \%$ in 2070 (European Commission, 2018). LTC provision in Europe is characterized by significant differences between countries, concerning the provision model (public, for-profit or nongovernmental providers), the nature (home care versus institutional care), financing (cash benefits, in-kind benefits or out-of-pocket payments) and resources generation methods (via general taxation, mandatory social security and/or voluntary private insurance; Spasova et al., 2018). Several inquiries reveal that despite relative progress in the distribution of the caregiving burden, women continue to assume responsibility for carrying out most caregiving (Le Bihan, Da Roit, \& Sopadzhiyan, 2019). Further, women are far more likely than men to reduce their working hours or to leave employment in order to provide care (Haberkern, Schmid, \& Szydlik, 2015). In several countries, home care is gaining priority over residential care, but formal home care services for the elderly remain underdeveloped in many Southern and Central and Eastern European countries (Spasova et al., 2018, p. 6). Due to the growing priority for home care, residential care capacities have been decreasing in several European countries over the past 25 years. Nordic countries have implemented significant deinstitutionalization in support of home and other forms of care (Greve, 2017). In Southern Europe, however, LTC beds for people aged 65+ are on the rise through noteworthy reform measures. More robust formal care services in LTC are in progress, in particular in Spain (León \& Pavolini, 2014). This is due to growing women's participation, the increase in the pensionable age, and changes in family patterns. The main direction of changes in Central and Eastern Europe is less clear-cut (Spasova et al., 2018, p. 7).

The literature that has inspired and informed us uncovers intensive reform movements and changes in the 
European systems of LTC. One of the crucial conceptual, regulatory, and institutional transformations shapes up along the notion of familialization and defamilialization, that is, the ways in which care work is delivered by family members or by other care providers. Due to recent policy reforms unpaid work in the private sphere of the family has partly been transformed into formal, paid care work in the formal employment system outside the family. Still, several older people receive care by female family members (Pfau-Effinger, Eggers, Grages, \& Och, 2017, p. 3). The dual notion of formal and informal care resonates with the split of public- and family-based organization of caring-but it is not identical to it. Formal care is usually provided by trained and qualified professionals employed and regulated by the state, municipalities, or market and non-profit organizations. Formal care may be provided in residential and home contexts. Formal caregivers are paid and entitled to social rights and working regulations. Informal carers are individuals with direct personal ties to the cared as family members, friends, or neighbors. They are not contracted and often do not have regulated working hours/time. They do or do not have general entitlements to social welfare. Cash for care $(\mathrm{CfC})$ provisions bridge these two domains of care by allowing the recipient to choose the forms of care $s /$ he uses the cash support for (Da Roit \& Le Bihan, 2010).

A recent comparative inquiry investigating formal and informal care provision for people ages 65 and over identified three country groups in Europe, which is not particularly surprising. The Nordic and the continental countries with robust welfare systems compose the first group, where more than $60 \%$ of people in need of care receive formal care. The second group consists of countries where $35 \%$ to $45 \%$ of people in need of care receive formal care, which encompasses the Southern European countries. The third group, where less than $35 \%$ of people in need receive formal care, includes Central and Eastern European countries. At the same time, when the ratio of people receiving only informal care is considered, Southern and Central and Eastern European countries stand together (Barbieri \& Ghibelli, 2018). These results resonate with Esping-Andersen's (1990) well-known welfare typology.

Another recent comparative study uncovers how informal care and, within that, CfC schemes shapes LTC systems (Le Bihan et al., 2019). Engaging with the debate on the consequences of familialization versus defamilialization policies (Leitner, 2014; Saraceno, 2010, 2016), the researchers propose a conceptual framework to explain recent LTC reforms and their outcomes. Most importantly, it is argued that defamilialization enables care users to organize their own care arrangement through compensation of family carers, or the purchase of professional (private or public) services. With great variations within a larger trend, it can be observed that several European countries have been increasingly moving towards familialistic care arrangements in the 2010s in various compositions, in which market and family ser- vices may be supported in different ratios (Le Bihan et al., 2019). Another comparative study (on five different welfare states) challenges the common assumption that generous support for caring family members is mainly used as a cheap substitute for extra-familial care by public support. This inquiry finds that, somewhat surprisingly, welfare state policies towards LTC for senior citizens are either generous or less generous in both modalities of care services, that is, family-based and extra-familial caser services (Pfau-Effinger et al., 2017, p. 3). It remains a prime interest for a growing body of cross-national and comparative research whether the systemic relations between formal and informal care is complementarity or substitution based (Verbakel, 2018).

Recent scholarship reveals that women remain the most important caregivers in LTC and the responsibility of supervising, coordinating, and assessing care falls on them (Le Bihan et al., 2019, p. 580). Informal care, especially if performed at higher intensity or for longer periods, has an impact on carers' employment prospects, social participation, and mental and physical health (Barbieri \& Ghibelli, 2018). Home-based personal care work is labor-intensive, and can be emotionally and physically demanding. It is often carried out in substandard working conditions and without regulation or legal protection. Informal carers may face difficulties in securing reliable pensions and thus risk poverty and their own LTC at pension age (Eurocarers, 2016). If the burden of informal care is disproportionately taken by particular social groups, care will have major in/equality consequences. In various European contexts, a wider 'social contract' still values and normalizes care as women's duty and prime capability, hence the continued gender inequality concerns with informal versions of caring.

Although the gender inequality promoting effects of informal care are tangible and well documented, Ciccia and Sainsbury (2018) warn that the outcomes of defamilialization should be carefully scrutinized against the powerful feminist assumptions about the liberating effects of unravelling care work from women's home duties. Indeed, defamilialization does not provide an unambiguous route to gender equality as public care jobs are mostly taken by women for lower pay. Without incorporating paid and care work on equal terms into social and political citizenship a transformative gender order will not arise. On a positive note, informal care does not exclude the principle of gender equality if it is not a moral claim and caregivers have autonomous choices (Ciccia \& Bleijenbergh, 2014, p. 8).

Finally, the literature we rely on argues that the trend of refamilialization, but to a certain extent all forms of care work, may imply care labor force replacement by migrant workers (van Hooren et al., 2019). Care provided by immigrant women also shapes the gender division of labor in families and societies. Migrant care work both supports and undermines gender equality principles and transformative impulses in the care receiving states. The transfer of informal care to immigrant domestic work- 
ers allows women to join the workforce, but it also reaffirms the gendered nature of care since caring tasks and household chores remain largely in the hands of women (Ciccia \& Sainsbury, 2018; Lutz, 2018). Relying on migrant care work in the family, especially if this form of work remains poorly regulated and paid, perpetuates the exploitation impacts of transboundary care chains with negative repercussions on gender equality in migrants' home countries.

\section{Methodology and Data}

We apply fuzzy-set ideal type analysis (FSITA) to understand the configurations of LTC in Europe. In the last two decades FSITA has been increasingly used in analysis of welfare regime change and in building childcare policy typologies (Ciccia, 2017; Ciccia \& Bleijenbergh, 2014; Da Roit \& Weicht, 2013; Kvist, 1999; Szelewa \& Polakowski, 2008; Vis, 2007). In the particular steps of applying FSITA we follow the sequences suggested by Kvist (2007): First, we anchor our typology to theoretically defined ideal types; then, we operationalize our theoretical expectations related to the ideal types at the level of empirical variables; third, we calibrate the values of variables; and finally, we assess the conformity of national LTC policies to the ideal types.

Similarly to Ciccia and Bleijenbergh (2014) or Lauri, Põder, and Ciccia (2020), we started our ideal type building inspired by Fraser (1994). LTC policies, however, are much less crystallized than childcare policies. In particular, gender equal contribution to the double carer (in Fraser's [1994] words, the "universal caregiver") component of the double earner and double carer normative ideal seems missing in LTC; as an implication, in sharp contrast to childcare leave policies, there are no specific incentives to enhance male participation in LTC. At the same time, there are care regime type differences concerning the level of support for familial care. Accordingly, we distinguished three models of LTC policies: the male breadwinner, the double earner but unsupported carer, and the double earner and supported carer ideal types.

Deriving from the theoretical discussion in the previous section, our ideal types are built upon four dimensions: the generosity of LTC expenditures (G), the level of unmet care needs $(U)$, the quality of home care regulation $(R)$, and the employment gap between men and women (E). While the first three dimensions ( $G, U$, and R) capture the care regime features of national policy configurations, the last dimension refers to the employment dimension (E) by comparing the time share of men and women in paid work through a full-time equivalent perspective. As there are no systematically elaborated data sets that provide data fitting the conceptualization in our research, we constructed the operationalized variables as proxy variables from multiple sources. In the data selection process, we used the most recent data collected by international institutions for the post-crisis period; when various measurements were available, period average values were used. Table 1 summarizes the theoretically-based expectations along the ideal type dimensions in fuzzy-set theory terms. A detailed description of these dimensions in the form of operationalized variables' values as well as the specific content and the sources of the variables is provided in the notes section of Table 2.

In the process of calibration (i.e., the transformation of empirical values into 0-1 fuzzy scores along the ideal type dimensions), we rely on the substantive knowledge of LTC scholarship. In addition, we apply the major principles and rules of fuzzy-set theory: the minimum principle and the intersection rule for logical AND relations, the complement rule for logical negation and the maximum principle and the rule of union for logical OR relations (Kvist, 2007, p. 476).

When assessing the conformity of individual countries to the ideal type varieties, our empirical expectation is that only a minority of national care policy configurations in the EU will belong to the double earner, supported carer ideal type. While we do not assume the prevalence of the male breadwinner model (that implies the female carer normative ideal as well), we expect that most of the EU member states exhibit a hybrid pattern and oscillate between the double earner, unsupported carer and the double earner supported carer models.

Concerning the gender equality outcome, we expect a clear ranking of the ideal types as the level of supporting policy of carers logically develops parallel to gender equality policies. In addition, migrants' incorporation in national care regimes is expected to be the most significant in countries close to the double earner, unsupported carer ideal type. In this respect, scarcity and uncertainty of care migration data is an important limita-

Table 1. Property space of LTC policy ideal types.*

\begin{tabular}{lcccc}
\hline & $\begin{array}{c}\text { Generosity of LTC } \\
\text { expenditures (G) }\end{array}$ & $\begin{array}{c}\text { Unmet care } \\
\text { needs (U)** }\end{array}$ & $\begin{array}{c}\text { Quality of home } \\
\text { care regulation (R) }\end{array}$ & $\begin{array}{c}\text { Full-time equivalent } \\
\text { employment gap (E)** }\end{array}$ \\
\hline Male breadwinner & $\sim \mathrm{G}$ or $\mathrm{U}$ & $\mathrm{U}$ & $\sim \mathrm{R}$ & $\sim \mathrm{E}$ \\
Double earner, unsupported carer & $\sim \mathrm{G}$ & $\sim \mathrm{U}$ & $\sim \mathrm{R}$ & $\sim \mathrm{E}$ or $\mathrm{E}$ \\
Double earner, supported carer & $\mathrm{G}$ & $\mathrm{U}$ & $\mathrm{R}$ & $\mathrm{E}$ \\
\hline
\end{tabular}

Notes: * upper case letters indicate membership in a set, while letters preceded by a tilde ( ) indicate the absence of the set. ** Membership in a set is defined as the more supportive care policy in each of the dimensions, thus set membership indicates low unmet care needs and lower full-time equivalent employment gap between men and women. 
Table 2. Raw data used for the FSITA of European LTC regimes.

\begin{tabular}{|c|c|c|c|c|}
\hline & $\begin{array}{l}\text { Generosity of LTC } \\
\text { expenditures (1) }\end{array}$ & $\begin{array}{c}\text { Unmet care } \\
\text { needs (2) }\end{array}$ & $\begin{array}{l}\text { Quality of home } \\
\text { care regulation (3) }\end{array}$ & $\begin{array}{l}\text { Full-time equivalent } \\
\text { employment gap (4) }\end{array}$ \\
\hline Austria & 1.9 & 30.0 & 0.75 & 19 \\
\hline Belgium & 2.3 & 26.5 & 0.75 & 15 \\
\hline Bulgaria & 0.4 & 60.5 & 0.50 & 11 \\
\hline Croatia & 0.9 & 41.1 & 0.25 & 12 \\
\hline Cyprus & 0.3 & 74.1 & 0.50 & 13 \\
\hline Czech Republic & 1.3 & 40.9 & 0.75 & 18 \\
\hline Denmark & 2.5 & 23.3 & 0.75 & 10 \\
\hline Estonia & 0.9 & 17.6 & 0.75 & 15 \\
\hline Finland & 2.2 & 7.8 & 0.75 & 8 \\
\hline France & 1.7 & 20.5 & 0.75 & 12 \\
\hline Germany & 1.3 & 20.1 & 0.75 & 20 \\
\hline Greece & 0.1 & 87.7 & 0.25 & 17 \\
\hline Hungary & 0.7 & 46.7 & 0.50 & 20 \\
\hline Ireland & 1.3 & 33.9 & 0.75 & 17 \\
\hline Italy & 1.7 & 51.8 & 0.25 & 20 \\
\hline Latvia & 0.4 & 62.6 & 0.50 & 13 \\
\hline Lithuania & 1.0 & 34.3 & 0.50 & 10 \\
\hline Luxembourg & 1.3 & 17.1 & 0.75 & 15 \\
\hline Malta & 0.9 & 34.6 & 0.50 & 25 \\
\hline Netherlands & 3.5 & 20.5 & 0.75 & 21 \\
\hline Poland & 0.5 & 42.8 & 0.50 & 20 \\
\hline Portugal & 0.5 & 51.1 & 0.50 & 11 \\
\hline Romania & 0.3 & 60.0 & 0.50 & 17 \\
\hline Slovakia & 0.9 & 42.2 & 0.50 & 17 \\
\hline Slovenia & 0.9 & 46.1 & 0.75 & 14 \\
\hline Spain & 0.9 & 44.9 & 0.50 & 13 \\
\hline Sweden & 3.2 & 12.7 & 0.75 & 8 \\
\hline United Kingdom & 1.5 & 18.2 & 0.75 & 19 \\
\hline European Union* & 1.3 & 38.2 & $(0.60)$ & 15 \\
\hline
\end{tabular}

Notes: *unweighted average. (1) Public expenditures on LTC (long-term nursing care and social care) as \% of GDP, 2016. Source: European Comission (2018); (2) Households experiencing difficulty or great difficulty in affording professional home care services as a \% of all households that pay for home care services. Source: Eurofound (2019); (3) Qualitative assessment of home care services' regulation (0: weak; 0.25: rather weak; 0.5 : medium; 0.75 : strong; 1 : very strong) based on document analysis of data provided by Mutual Information System on Social Protection (2019) in the member states of the EU; (4) Full-time equivalent employment rate gap between men and women in \%-points. Source: European Institute for Gender Equality (2019).

tion of our study. The content and the sources of the gender equality and migration variables is provided in the notes section of Table 3 .

\section{Findings}

While none of the countries conform to the male breadwinner ideal type, half of the EU member states do not clearly belong to any of the LTC ideal types (see Table 4). These countries exhibit a hybrid character, fitting loosely either the double earner, unsupported carer or the double earner, supported carer models. Therefore, our results yield a four-pronged ideal type scheme of LTC in European countries. These results contained both anticipated and surprising elements (see Table 5).

Four Southern European countries and Bulgaria, Romania, and Latvia belong to the double earner and unsupported carer model. Whereas the employment par- ticipation gap between men and women is of middle value, the relatively low generosity of the LTC support becomes a decisive factor in the model. It is plausible that the countries associated with this ideal type show relatively high unmet care needs. This model overall resonates with what Le Bihan, et al. (2019) call unsupported familialism. Society relies on but only modestly supports the provision of care by the family, whereas most women are at work. In general, unmet care needs are high in the countries concerned here and families are the main sites and resources for LTC. The notion of 'unsupported' in the name of the cluster stands for a variety of provisions which rely on informal human relations and family resources, but occasionally with some tangible support for the care recipients and their families. In countries with no strict requirements on its use, cash benefit is frequently used to recruit informal domestic workers, which pertains to Cyprus, Italy, Latvia, and Romania in the 
Table 3. Gender equality in care activities and migrants' incorporation in national care regimes.

\begin{tabular}{|c|c|c|c|c|c|}
\hline & \multirow[b]{2}{*}{$\begin{array}{l}\text { Gender equality in } \\
\text { care activities (1) }\end{array}$} & \multicolumn{2}{|c|}{ 'Captured' carers (2) } & \multicolumn{2}{|c|}{ Home-based caregivers in the labour force (3) } \\
\hline & & $\begin{array}{l}\text { Migrant } \\
\text { women }\end{array}$ & $\begin{array}{c}\text { Women in general } \\
\text { population }\end{array}$ & $\begin{array}{l}\text { Home-based } \\
\text { caregivers }\end{array}$ & $\begin{array}{c}\text { Share of foreign-born among } \\
\text { home-based caregivers }\end{array}$ \\
\hline Austria & 62.1 & 14.0 & 13.8 & 0.5 & 29.6 \\
\hline Belgium & 71.2 & 10.0 & 8.0 & 0.8 & 14.6 \\
\hline Bulgaria & 56.0 & n.a. & n.a. & n.a. & n.a. \\
\hline Croatia & 57.6 & n.a. & n.a. & n.a. & n.a. \\
\hline Cyprus & 61.4 & 32.0 & 14.8 & n.a. & n.a. \\
\hline Czech Republic & 57.7 & n.a. & n.a. & 0.7 & 1.7 \\
\hline Denmark & 85.9 & 5.0 & 3.2 & n.a. & n.a. \\
\hline Estonia & 81.6 & n.a. & n.a. & 0.5 & 4.5 \\
\hline Finland & 83.5 & 10.0 & 14.7 & 0.9 & n.a. \\
\hline France & 73.1 & 29.0 & 14.7 & 0.1 & n.a. \\
\hline Germany & 69.6 & 18.0 & 16.0 & 0.1 & 10.8 \\
\hline Greece & 52.3 & n.a. & 7.2 & 0.1 & 74.5 \\
\hline Hungary & 67.2 & n.a. & n.a. & 0.3 & n.a. \\
\hline Ireland & 78.0 & 33.0 & 22.6 & 0.1 & n.a. \\
\hline Italy & 63.3 & 47.0 & 15.0 & 1.0 & 89.0 \\
\hline Latvia & 84.9 & n.a. & n.a. & n.a. & n.a. \\
\hline Lithuania & 67.5 & n.a. & n.a. & n.a. & n.a. \\
\hline Luxembourg & 77.9 & 4.0 & 8.8 & 0.2 & 50.0 \\
\hline Malta & 65.3 & n.a. & 12.2 & n.a. & n.a. \\
\hline Netherlands & 78.9 & 24.0 & 11.2 & 1.4 & 14.3 \\
\hline Poland & 64.6 & 32.0 & 16.0 & 0.2 & 1.6 \\
\hline Portugal & 65.4 & 9.0 & 7.4 & 0.1 & n.a. \\
\hline Romania & 73.2 & n.a. & n.a. & n.a. & n.a. \\
\hline Slovakia & 58.5 & n.a. & n.a. & 1.6 & 0.4 \\
\hline Slovenia & 70.4 & 33.0 & 3.8 & 0.2 & n.a. \\
\hline Spain & 73.5 & 36.0 & 9.7 & 0.4 & 67.4 \\
\hline Sweden & 88.1 & 3.0 & 7.2 & 5.0 & 22.2 \\
\hline United Kingdom & 77.0 & 37.0 & 28.0 & 2.7 & 18.8 \\
\hline
\end{tabular}

Notes: (1) Gender Equality Index scores in care activities, 2012-2017 averages. Source: European Institute for Gender Equality (2019); (2) Women aged 15-64 stating that they do not look for a job because of care activities. Source: European Union Agency for Fundamental Rights (2016); (3) Share of home-based caregivers in the labour force (\%) and share of foreign-born among home-based caregivers (\%). Source: King-Dejardin (2019, pp. 36-37).

cluster (Spasova et al., 2018, p. 17). Gender equality in care work is usually modest in these countries, excepting the outlier Latvia, where we can assume some broader equalitarian or solidarity driven social practices. Feminist care scholarship supports the assumption that when unmet needs are high or rising, without much other support, women-even in employment but often in parttime and lower-paid jobs-will be the ones who step in as service providers. The possible replacement for these women may come from migrant care work, as in the cases of Italy and Greece (see Table 3). Migrant carers, often without a proper employment contract or work permit, are also typically women, which taps into the resources of the well documented care chain with tangible gender inequality effects.

Categorized in the loosely fitting to the double earner and unsupported carer model are three Visegrad countries, Spain, Croatia, and Lithuania. In this highly mixed group of countries, the generosity of the overall public support to care services is modest; the full-time equiva- lent employment participation between men and women varies; and the unmet care needs are tangibly lower than in the former country group yet still significant. The gender equality in care work index is of middle values except for Spain, which stands out with relatively high performance in this respect. It is noteworthy that the average gender equality score in care in this country group is not higher than in the former one (see Table 3). Thus, the tangible higher generosity of LTC support and the lower level of unmet care needs together elevate countries to this model. These two properties of the LTC regime make the gender equality potentials of care higher in these countries than in the first country group. Further research is needed to explore if the better figures for unmet care needs in the Visegrad states and Spain are due to various LTC reforms implemented in recent years. According to our data, the overall generosity of LTC support in some Visegrad countries is growing and the regulatory support to home care is reasonable. Since the introduction of a major reform in 2006, Spain has moved towards a mixed 
Table 4. Fuzzy-set membership scores by ideal types.

\begin{tabular}{|c|c|c|c|}
\hline & Male breadwinner & Double earner, unsupported carer & Double earner, supported carer \\
\hline Austria & 0.27 & 0.25 & 0.54 \\
\hline Belgium & 0.21 & 0.25 & 0.66 \\
\hline Bulgaria & 0.16 & 0.50 & 0.11 \\
\hline Croatia & 0.17 & 0.41 & 0.25 \\
\hline Cyprus & 0.19 & 0.50 & 0.09 \\
\hline Czech Republic & 0.25 & 0.25 & 0.37 \\
\hline Denmark & 0.14 & 0.14 & 0.71 \\
\hline Estonia & 0.21 & 0.18 & 0.26 \\
\hline Finland & 0.11 & 0.08 & 0.63 \\
\hline France & 0.17 & 0.21 & 0.49 \\
\hline Germany & 0.29 & 0.20 & 0.37 \\
\hline Greece & 0.12 & 0.75 & 0.03 \\
\hline Hungary & 0.29 & 0.47 & 0.20 \\
\hline Ireland & 0.24 & 0.25 & 0.37 \\
\hline Italy & 0.29 & 0.51 & 0.25 \\
\hline Latvia & 0.19 & 0.50 & 0.11 \\
\hline Lithuania & 0.14 & 0.34 & 0.29 \\
\hline Luxembourg & 0.21 & 0.17 & 0.37 \\
\hline Malta & 0.39 & 0.35 & 0.26 \\
\hline Netherlands & 0.30 & 0.00 & 0.70 \\
\hline Poland & 0.29 & 0.43 & 0.14 \\
\hline Portugal & 0.16 & 0.50 & 0.14 \\
\hline Romania & 0.24 & 0.50 & 0.09 \\
\hline Slovakia & 0.24 & 0.42 & 0.26 \\
\hline Slovenia & 0.20 & 0.25 & 0.26 \\
\hline Spain & 0.19 & 0.45 & 0.26 \\
\hline Sweden & 0.14 & 0.09 & 0.75 \\
\hline United Kingdom & 0.27 & 0.18 & 0.43 \\
\hline
\end{tabular}

Notes: Scores in bold designate fuzzy-set membership ( $\geq 0.5$ ). A higher score indicates a closer correspondence between a country's LTC policy and the ideal type.

model of LTC with an increasing role for the public sector and regulated family care services, in spite of resource redistribution and governance challenges and post-2008 austerity measures (Arlotti \& Aguilar-Hendrickson, 2018; León \& Pavolini, 2014). As this cluster is mostly composed by Central and Eastern European countries (including Croatia and Lithuania), migrant labor participation in care work is not significant, at least it is not captured by official statistics. Migrant workers' participation in homebased care is particularly high in Spain with mixed gender equality effects.

The loosely fitting to double earner and supported carer model comprises the most diverse mix in any of the groups, including the two largest countries of the

Table 5. Gender equality scores by ideal types.

\begin{tabular}{llc}
\hline Country groups by fuzzy-set ideal types & Countries & $\begin{array}{c}\text { Average Gender Equality Index scores } \\
\text { in care activities by country groups* }\end{array}$ \\
\hline $\begin{array}{l}\text { Countries close to double earner, } \\
\text { unsupported carer ideal type }\end{array}$ & $\begin{array}{l}\text { Bulgaria, Cyprus, Greece, Italy, } \\
\text { Latvia, Portugal, Romania }\end{array}$ & 65.2 \\
$\begin{array}{l}\text { Countries loosely fitting the double earner, } \\
\text { unsupported carer ideal type }\end{array}$ & $\begin{array}{l}\text { Croatia, Hungary, Lithuania, } \\
\text { Poland, Slovakia, Spain }\end{array}$ \\
$\begin{array}{ll}\text { Countries loosely fitting the double earner, } \\
\text { supported carer ideal type }\end{array}$ & $\begin{array}{l}\text { Czech Republic, Estonia, France, } \\
\text { Germany, Ireland, Luxembourg, } \\
\text { Slovenia, United Kingdom }\end{array}$ \\
Countries close to double earner, & $\begin{array}{l}\text { Belgium, Denmark, Netherlands, } \\
\text { supported carer ideal type }\end{array}$ & 73.2 \\
\hline Note: * Average values of Gender Equality Index scores in the 2012-2017 period. Source: European Institute for Gender Equality (2019).
\end{tabular}


continental welfare regime, two Anglo-Saxon countries and the Czechia, Estonia, and Slovenia trio from Central and Eastern Europe. The generosity of overall spending is higher than the European average in these settings but there are profound differences in the unmet needs. The home care services are usually highly regulated. The fulltime employment rate gap between men and women is still significant, which tends to support the expectations and practices of supported familialism in care. The gender equality index of care work is relatively high, and outstanding in Estonia. The reasons behind this performance might be similar to what we assume in the case of Latvia's paramount gender equality value regarding care duties in the first group. The composition of scores assigning Czechia to this cluster is quite different: The lower gender equality in care score is accompanied by a high generosity of LTC expenditures compared to other Central and Eastern Europe countries. The care work replacement by migrant carers is high in Germany and the United Kingdom, which reveals that the cross-border care chain resource may give major assistance to very differently organized but well-regulated care systems. It surely limits fully transformative gender relations in care in wider societal terms, but it does not prevent a reasonably good gender equality index compared to regimes in the first two models. Informal carers often face difficulties in accumulating sufficient pension funds even in generous LTC regimes as well, yet Germany stands out with its mechanisms for carers to build up pension rights. This is likely to have positive effects on gender equality (Barbieri \& Ghibelli, 2018, p. 17), but its distribution across classes and citizenship background is a further important inequality quest.

The fourth model enacts a close to double earner and supported carer scheme. As it encompasses high generosity of overall domestic care spending, highly regulated care services, and relatively low unmet needs, it is not surprising that Nordic countries and smaller and rich continental countries are associated with it. The Nordic countries and the Netherlands have generous LTC systems with widely available formal care services. In these settings, informal care is a choice rather than a substitute for the formal one (Heger \& Korfhage, 2018). Austria makes the grade, too, but with the lowest fuzzy-set membership score, stemming from a relatively low gender equality value in care activities but with generous overall LTC spending.

The gender equality score in care work is high in these countries. This constellation is shaped by varying degrees of gender employment rate gaps, which implies high material, institutional, and regulatory support to familialism. This can compensate the possible setbacks of a gender gap in full-time equivalent employment, which is still tangible in Austria and the Netherlands. It is important to note that in Austria, Belgium, the Netherlands, and Sweden, the involvement of migrant domestic care workers is significant according to our data (see Table 3). This suggests that gender equality progress for middle- class families has been achieved at the price of maintaining the gender imbalance in providing care at the societal level and through the often exploitative cross-border care chain. In Austria '24-hour care' at home is almost entirely provided by migrant workers, mainly from Slovakia and Romania (Bauer \& Österle, 2016; Sekulová \& Rogoz, 2018). This form of work has been regulated since 2007 : Care workers can register as self-employed or directly employed by families. This enables them to have access to social and health care benefits, yet they are paid less than regular care employees (Österle \& Bauer, 2016).

\section{Discussion and Conclusions}

Different voices in the literature seem to converge in the understanding that family-based care is prevalent and growing in LTC systems in Europe. This is encouraged by $\mathrm{CfC}$ solutions, increasingly regulated care service markets, standardization of the profession, and various work-care reconciliation measures. Le Bihan et al. (2019), Spasova et al. (2018), and others suggest that there is a major shift towards familialism where home-care is fostered and often supported, and a form of choice is given to families to purchase paid care. In some countries, formerly preferred and developed residential care systems become streamlined. Home-based care and growing familialism has fundamentally been supported and maintained by migrant care work in a number of countries of Europe, with great geographical spread. Central and Eastern Europe has become a major supplier of this migrant labour force in the last decade. To capture the transient and more enduring changes in LTC and general social reproduction, we have turned to the intersections of care regime, gender regimes, and migration regimes. We have more reliable and comparable data on the first two domains which sets limitations on our work.

Through only a snapshot, our results resonate with the overall landscape of familialization in LTC by revealing that most countries belong to some sort of hybrid policy regimes. We have experimented with a regime typology by incorporating both policy input and output data on LTC resources and care giving modes, insights in the schematic social contract between families and other societal institutions, and indicators of gender relations. We also portrayed that hybrid regimes generate diverse gender in/equality conditions. Positive outliers prove that transformative gender relations in care can be construed not only in the richest and most generous welfare countries in Europe. Our findings confirm the eye-opening results of the comparative research by Pfau-Effinger et al. (2017) in contesting the common assumption that generous support for caring family members is mainly used as a cheap substitute for welfare state provisions and residential care services. Accordingly, welfare measures for LTC are either generous in different areas of care or they are overall less generous; thus, the familial and the extra-familial care move together rather than against each other on a societal scale. By the same token, other 
important conditions of the care system, the regulation of home care services, the provisions of paid and unpaid care leave and work flexibility, and the regulation of migrant care work should be further explored as forces that have stand-alone as well as interlinked transformative gender equality potentials.

Our results engage with the gender scholarship on care in the European context, which tends to describe domestic work as a site of exploitation. Inequalities result from the unequal positioning of actors concerned in the care relations in households and society at large at the intersections of gender, class, and citizenship positions. There is, however, an understanding that domestic labor may become a proper employment and recognized as professional occupation (Sekulová \& Rogoz, 2018). But the formalization, recognition, and valuation of homebased care is slow and uneven across Europe, especially in view of the fast-growing needs among elderly people. The increasing significance of domestic care makes it essentially important to understand how ageing, employment, and gender relations are manifested in families' reactions to care challenges. Haberkern et al. (2015, p. 315) have revealed that daughters seem to be more willing than sons to interrupt their working careers in order to assist their parents in need of LTC, regardless of their employment position. It is particularly important to acknowledge this observation when cash benefit provisions are on the rise. Since men earn more than women in all European countries and care work is seen as women's duties, cash benefits predominantly activate women and thereby preserve the gendered organisation of care. It is proposed that achieving gender equality in intergenerational care is still a "one-way ticket from informal care by women towards state care" (Haberkern et al., 2015, p. 317) if men's participation does not increase.

Our modest results also speak to the transnational care chain and 'care drain' scholarship that emphasizes unmet care duties of migrant carers in their home countries and the detrimental effects of migrant laborer conditions on children and elderly in the family. In addition to the highly recognized and influential research results by the leading care drain scholars, some recent empirical inquiries refine and redraw the picture of gender division of care work. In-depth qualitative investigations on Central and Eastern European women engaged in cross-border care practices propose that these women find ways to avoid care gaps in their families. For example, Bahna and Sekulová $(2019$, p. 141) observed that Slovak carers typically engage in care work in Austria either only after the demise of their parents or stop working as care workers should their parents' needs for care increase. Many of these women reported overwhelmingly positive job evaluation and elevating emancipation in their socio-economic positions and even professional recognition compared to their opportunities in the home country (Bahna \& Sekulová, 2019, p. 142). The subjective experience with tangible emancipatory contents of migrant carers calls for further empirical research and theo- retical reflections on the gender in/equality impacts of cross-border care chains in which Central and Eastern European women meet the unmet needs in the rest of Europe.

Finally, our inquiry offers some-but only preliminary-contributions to a slowly growing knowledge on LTC mechanisms and gender in/equality dynamics in Central and Eastern Europe. The high figures on unmet LTC needs and relatively low public spending on LTC represent obvious reasons why home care services for the elderly have remained undeveloped in most of these countries. But behind the hybrid nature of these countries' LTC schemes, one can assume diverse gendered composition of the labor market and varyingly generous care leave policies at the workplace. In addition, political narratives, cultural models, and traditions of intergenerational solidarity all shape the configurations of policy paradigms and social practices in LTC. Hrženjak's (2019) qualitative case study on Slovenia invites large- $\mathrm{N}$ and comparative investigations to test her findings in wider regional settings. She argues that the actual familialization of elderly care is conditioned by traditional patterns of informal family care of state socialism and transitional conditions. The absence of an integrated LTC system seems typical for Central and Eastern Europe, in which institutional services are insufficient, expensive, and accessible only for the middle-class families. In contrast to childcare, elderly care is not yet high on the agenda of gender equality thinking among policy makers (Hrženjak, 2019, pp. 649-650). We add to this observation that, in the case of Central and Eastern European countries, further inquiries cannot avoid addressing that the actual shape and performance of LTC should be read against the specific consequences of care chain patterns in Europe. Arguably, these countries play, at least potentially, a double role: While they provide a significant part of the supply side of care providers for the elderly and the disabled in the Western and Southern parts of Europe, the relatively wealthier states among Central and Eastern European countries also play an increasing role on the demand side of global care chains.

Our study has some limitations. First, as comparative data about care migration are scarce, uncertain, and uneven across Europe, the suggested care migration-LTC regime nexus calls for further check, either by repeating our analysis in a smaller set of countries for which reliable care migration data is available, or by qualitative research methods used in comparative case studies. A second limitation is that in this study we have provided only a snapshot of LTC patterns in Europe, thus bifurcations in care policy trajectories are at best indirectly discussed. A third limitation stems from the predominantly hybrid character of European LTC regimes; as a result, our fuzzy-set categorization of European countries may mingle some apparently incongruent policy patterns. At the same time, this research may contribute to better understanding of LTC policy mechanisms shaping gender equalities in a broader European context and our findings may 
open avenues for future research at the intersections of care, gender, and migration regimes.

\section{Acknowledgments}

This study was inspired by an earlier research cooperation of the authors with Olena Fedyuk within the NEUJOBS research project financed by the European Commission under the 7th Framework Programme. The authors express their gratitude to all colleagues who encouraged the present research, the anonymous reviewers as well as the academic editors whose comments greatly improved the manuscript. They also thank Michael Zeller for copyediting the text.

\section{Conflict of Interests}

The authors declare no conflict of interests.

\section{References}

Arlotti, M., \& Aguilar-Hendrickson, M. (2018). The vicious layering of multilevel governance in Southern Europe: The case of elderly care in Italy and Spain. Social Policy \& Administration, 52(3), 646-661.

Bahna, M., \& Sekulová, M. (2019). Crossborder care. Cham: Palgrave Macmillan.

Barbieri, D., \& Ghibelli, P. (Eds.). (2018). Formal vs. informal long-term care: Economic \& social impacts. (SPRINT Working Paper D4.4.) Brussels: Social Protection Investment in Long-Term Care. Retrieved from http://sprint-project.eu/wp-content/uploads/ 2018/09/SPRINT_D4.4_Formal_vs_InformalLTC_Econocmic_Social_Impacts.pdf

Bartha, A., Fedyuk, O., \& Zentai, V. (2015). Low-skilled migration: Immigrant workers in European domestic care. In M Beblavý, I. Maselli, \& M. Veselkova (Eds.), Green, pink \& silver? The future of labour in Europe (Vol. 2, pp. 237-257). Brussels: Center for European Policy Studies. Retrieved from https://www. ceps.eu/wp-content/uploads/2015/03/NEUJOBS\%20 Future\%20of\%20Labour\%20Vol\%20II_Final.pdf

Bauer, G., \& Österle, A. (2016). Mid and later life care work migration: Patterns of re-organising informal care obligations in Central and Eastern Europe. Journal of Aging Studies, 37, 81-93.

Ciccia, R. (2017). A two-step approach for the analysis of hybrids in comparative social policy analysis: A nuanced typology of childcare between policies and regimes. Quality \& Quantity, 51(6), 2761-2780.

Ciccia, R., \& Bleijenbergh, I. (2014). After the male breadwinner model? Childcare services and the division of labor in European countries. Social Politics, 21(1), 50-79.

Ciccia, R., \& Sainsbury, D. (2018). Gendering welfare state analysis: Tensions between care and paid work. European Journal of Politics and Gender, 1(1/2), 93-109.
Da Roit, B., \& Le Bihan, B. (2010). Similar and yet so different: Cash-for-care in six European countries' long-term care policies. The Milbank Quarterly, 88(3), 286-309.

Da Roit, B., \& Weicht, B. (2013). Migrant care work and care, migration and employment regimes: A fuzzyset analysis. Journal of European Social Policy, 23(5), 469-486.

Daly, M. (2011). What adult worker model? A critical look at recent social policy reform in Europe from a gender and family perspective. Social Politics, 18(1), 1-23.

Esping-Andersen, G. (1990). The three worlds of welfare capitalism. Princeton, NJ: Princeton University Press.

Eurocarers. (2016). Supporting informal carers: Developing social rights and seizing the opportunity to rebalance the European Union. Brussels: European Commission. Retrieved from https://ec.europa.eu/social/ BlobServlet?docld=17408\&langld=en

Eurofound. (2019). Quality of health and care services in the EU. Luxembourg: Eurofound.

European Commission. (2018). The 2018 ageing report: Economic and budgetary projections for the 28 EU member states (2016-2070) (European Economy Institutional Paper 079). Brussels: European Commission. Retrieved from https://ec.europa.eu/info/ sites/info/files/economy-finance/ip079_en.pdf

European Institute for Gender Equality. (2019). Gender Equality Index 2019. Work-life balance. Vilnius: European Institute for Gender Equality.

European Union Agency for Fundamental Rights. (2016). Second European Union minorities and discrimination survey. Migrant women: Selected findings. Luxembourg: Publications Office of the European Union.

Fraser, N. (1994). After the family wage: Gender equity and the welfare state. Political Theory, 22(4), 591-618.

Greve, B. (2017). Long-term care in Denmark, with an eye to the other Nordic welfare states. In B. Greve (Ed.), Long-term care for the elderly in Europe: Development and prospects (pp. 168-184). Abingdon: Routledge.

Haberkern, K., Schmid, T., \& Szydlik, M. (2015). Gender differences in intergenerational care in European welfare states. Ageing \& Society, 35(2), 298-320.

Heger, D., \& Korfhage, T. (2018). Care choices in Europe: To each according to his or her needs? INQUIRY: The Journal of Health Care Organization, Provision, and Financing, 55, 1-16.

Hrženjak, M. (2019). Multi-local and cross-border care loops: Comparison of childcare and eldercare policies in Slovenia. Journal of European Social Policy, 29(5), 640-652.

King-Dejardin, A. (2019). The Social Construction of Migrant Care Work. At the intersection of care, migration and gender. Geneva: International Labour Office.

Kvist, J. (1999). Welfare reform in the Nordic countries in the 1990s: Using fuzzy-set theory to assess confor- 
mity to ideal types. Journal of European Social Policy, 9(3), 231-252.

Kvist, J. (2007). Fuzzy set ideal type analysis. Journal of Business Research, 60(5), 474-481.

Lauri, T., Põder, K., \& Ciccia, R. (2020). Pathways to gender equality: A configurational analysis of childcare instruments and outcomes in 21 European countries. Social Policy \& Administration, 1-20. Advance online publication. https://doi.org/10.1111/spol.12562

Le Bihan, B., Da Roit, B., \& Sopadzhiyan, A. (2019). The turn to optional familialism through the market: Long-term care, cash-for-care, and caregiving policies in Europe. Social Policy \& Administration, 53(4), 579-595.

Leitner, S. (2014). Varieties of familialism: Developing care policies in conservative welfare states. In P. Sandermann (Ed.), The end of welfare as we know it? (pp. 37-51). Toronto: Barbara Budrich.

León, M., \& Pavolini, E. (2014). 'Social investment' or back to 'familism': The impact of the economic crisis on family and care policies in Italy and Spain. South European Society and Politics, 19(3), 353-369.

Lewis, J. (2006). Employment and care: The policy problem, gender equality and the issue of choice. Journal of Comparative Policy Analysis, 8(2), 103-114.

Lewis, J., \& Giullari, S. (2005). The adult worker model family, gender equality and care: The search for new policy principles and the possibilities and problems of a capabilities approach. Economy and Society, 34(1), 76-104.

Lister, R. (1997). Citizenship: Towards a feminist synthesis. Feminist Review, 57(1), 28-48.

Lutz, H. (2018). Care migration: The connectivity between care chains, care circulation and transnational social inequality. Current Sociology, 66(4), 577-589.

Mutual Information System on Social Protection. (2019). Comparative tables [Data set]. Retrieved from https://www.missoc.org/missoc-database/ comparative-tables/results

Österle, A., \& Bauer, G. (2016). The legalization of rotational 24-hour care work in Austria: Implications for migrant care workers. Social Politics, 23(2), 192-213.

Pfau-Effinger, B., Eggers, T., Grages, C., \& Och, R. (2017). Care policies towards familial care and extra-familial care: Their interaction and role for gender equality. Paper presented at the Transforming Care Conference, Milan, Italy.

Saraceno, C. (2010). Social inequalities in facing old-age dependency: A bi-generational perspective. Journal of European Social Policy, 20(1), 32-44.

Saraceno, C. (2016). Varieties of familialism: Comparing four southern European and East Asian welfare regimes. Journal of European Social Policy, 26(4), 314-326.

Sekulová, M., \& Rogoz, M. (2018). Impacts and particularities of care migration directed towards longterm care: Zooming in on Slovakia and Romania. Vienna: International Centre for Migration Policy Development.

Spasova, S., Baeten, R., Coster, S., Ghailani, D., PeñaCasas, R., \& Vanhercke, B. (2018). Challenges in longterm care in Europe: A study of national policies. Brussels: European Commission.

Szelewa, D., \& Polakowski, M. P. (2008). Who cares? Changing patterns of childcare in Central and Eastern Europe. Journal of European Social Policy, 18(2), 115-131.

van Hooren, F., Apitzsch, B., \& Ledoux, C. (2019). The politics of care work and migration. In A. Weinar, S. Bonjour, \& L. Zhyznomirska (Eds.), The Routledge handbook of the politics of migration in Europe (pp. 363-373). Abingdon: Routledge.

Verbakel, E. (2018). How to understand informal caregiving patterns in Europe? The role of formal long-term care provisions and family care norms. Scandinavian Journal of Public Health, 46(4), 436-447.

Vis, B. (2007). States of welfare or states of workfare? Welfare state restructuring in 16 capitalist democracies, 1985-2002. Policy \& Politics, 35(1), 105-122.

Williams, F. (2012). Converging variations in migrant care work in Europe. Journal of European Social Policy, 22(4), 363-376.

\section{About the Authors}

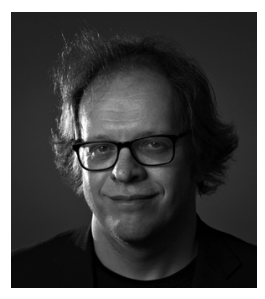

Attila Bartha is a Research Fellow at the Institute for Political Science of the Centre for Social Sciences and an Associate Professor at the Department of Public Policy, Institute for Economic and Public Policy, Corvinus University of Budapest. Since 2015 he has been a Founding Editor of the journal Intersections: East European Journal of Society and Politics. His main areas of research are comparative public policy, welfare policy, and political economy.

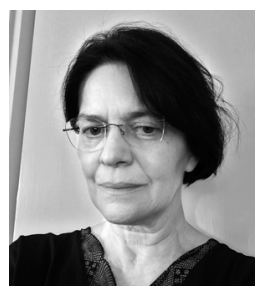

Violetta Zentai is a Social Anthropologist, Research Fellow and Co-director of the Center for Policy Studies, and Faculty Member of the School of Public Policy and the Department of Sociology and Social Anthropology at the Central European University. Her research focuses on ethnic and gender inequalities, post-socialist socio-economic transformations, political and policy debates on social inclusion, and pro-equality civil society formations. For more information visit: https://cps.ceu.edu/people/violettazentai 